\title{
Assessment of the Impact of Icts ICTs on Budget Processing In MDAs of Ondo State, Nigeria
}

\author{
Alade, M. Ezekiel ${ }^{1}$, Abiodun, Emmanuel ${ }^{2}$, Igbekoyi, Olusola Esther ${ }^{3}$ \\ ${ }^{1}$ Adekunle Ajasin University, Akungba-Akoko, Ondo State, Nigeria. \\ ${ }^{2}$ Ministry of Economic Planning and Budgeting, Ondo State, Nigeria. \\ ${ }^{3}$ Adekunle Ajasin University, Akungba-Akoko, Ondo State, Nigeria.
}

\begin{abstract}
Budget in public sector is an important tool for planning and implementating policies and decisions to achieve social, economic and political objectives. Governments around the world are looking for avenues to provide better services to their citizens and to also reduce cost of governance and services provided by them. This is fundamental to increasing set up of ICTs in rendering governments services to the governed. However, bureaucratic way of handling budgeting process is assumed to be one of the challenges facing timely readiness of budget in the State MDAs. Since ICT has been deployed by governments to carry out many of its functions, specifically in processing budget of its MDAs, the study therefore examines the impact of the use of ICT on budgeting process to find out whether it has reduced government bureaucracy, prolonged budgeting period and the cost associated with budgeting processes in Public Sector. The study rely on primary data obtained from samples purposively selected from 'the state's' MDAs and statistically analyzed using chi-square at 0.05 level of significance. The finding reveals that, ICT has significantly reduced budget processing time and cost related to the budget processing as well as fast-tracking timely readiness of the consolidated budget to be forwarded to the legislative arm. The study therefore suggests that government at all levels should see the use of ICTs for budget processing a must so as to earn reduction in associated cost in the long run and reduce the effect of bureaucratic feature of government on timely readiness of budget.
\end{abstract}

Key words: ICTs, MDAs, Bureaucracy, Budget, E-budgeting.

\section{Introduction:}

In public sector, it is widely believed that budgeting process usually take a long period of time and that it requires high cost. Studies have shown that it takes little more than an hour for the Minister of Finance or Minister of Economic Planning and budgeting to present a new national budget to the Parliament but it takes more than a year to prepare such budget. Budget is an important tool for planning and implementation of policies and decisions to achieve social, economic and political objectives (Planning and Budgeting Process in Tanzania). As much as this is, its relevance and importance may be affected if the process is carried out under a stressful condition which may affect the viability of the process.

Governments around the world are looking for avenues to provide better services to their citizens and to also reduce cost of governance and services provided by them. Information and Communication Technologies (ICT) is one of the innovations that have helped in nation building and development (Harindranath and Sien, (2004); Gatautis, (2008)) while its relevance in the aspect of budgeting process cannot be overemphasized. According to Adewoye \& Akanbi (2012), ICT is a complex and heterogeneous set of goods, applications and services used to produce, distribute, process and transform information. The efficiency and effectiveness of ICT in term of speed and accuracy can be relevant in the public sector's budgeting process. As regard to the cost implication of the use of ICT on products, Adewoye \& Akanbi further submitted that, ICT also brings about reduction of the cost of their products or services. A study carried out by Agbolade (2011) showed that there is a positive correlation between the use of ICT and Profitability. This shows some of the possible benefits that could be derived from the use of ICT in an establishment.

It is clear fact that so much money would have been spent to acquire and put in place some sets of ICTs. It is therefore expected that there should be some returns on such investment. On the hand, government is noted with bureaucracy (i.e. a system of government characterized by specialization of functions, adherence to fixed rules, and a hierarchy of authority). Bureaucratic way of handling budgeting process is assumed to be one of the challenges facing timely readiness of budget. According to Ronald \& Gary (1994), restructuring federal bureaucracy so that it "works better and cost less" was a major objective of the Clinton Administration. Probably that is why some governments are looking out for the 'less cost' or cost effective way of governance.

Since ICT has been deployed by governments to carry out many of its functions, specifically in processing budget of its Ministries, Department and Agencies (MDAs), there is need to examine if the use of ICT in budgeting process has reduced government bureaucracy, prolonged budgeting period and the cost 
associated with budgeting processes in Public Sector. The research questions asked to achieve the objective of the study are;

i. What are effects of ICT on the speed and cost of budgeting process in the MDAs?

ii. What is the impact of ICT on government bureaucratic budgeting process in the MDAs?

This study is expected to be of immense benefit to government at all levels by appreciating the need to process their budget with the use of ICTs. This is expected to earn government budgeting cost reduction, timely presentation of budget, maximum control over votes, staff ICTs compliance and above all making effort towards attaining vision 20:2020. Researcher who has interest in further study in this area will also benefit from the outcome of the study.

With the aim of establishing the impact of ICT on budgeting process in public sector empirically, the following null hypotheses were proposed and tested using Chi-square Statistical analysis

$\mathbf{H}_{\mathbf{O}}$ 1: The use of ICT to capture budget information in MDAs has no significant effect on budget processing speed;

$\mathbf{H}_{\mathbf{O}}$ 2: There is no significant reduction in the cost of processing budget in MDAs after the introduction of ICT;

$\mathbf{H}_{\mathbf{O}}$ 3: There is no positive impact of the use of ICT to process budget in MDAs on associated government bureaucracy.

$\mathbf{H}_{\mathbf{O}}$ 4: ICT does not provide better control over MDAs' Budget Processing

\section{Literature Review:}

Budget is a planning tool that identifies the work plan for the fiscal year and matches the financial, material and human resources available with the requirements to complete the work plan (Olajorin, 2012). In public sector, budget is a vehicle that helps to direct public expenditure towards the desired goals in accordance with the promises made by the Government of the day. Furthermore, scarcity of resources and the unlimited nature of societal needs make budget and budgeting an absolute imperative of government so that the society can maintain sustained economic growth overtime.

Budget also provides information on government and the policy direction under which the budget was prepared. Although a budget is often discussed as a financial document, the financial portion of a budget means very little without the policy and administrative information that tells stakeholders what Government intends to do with the available financial resources. Hence, the policy formulation aspect of the budget process is key to the success of the budget document.

\subsection{Conceptual Framework:}

\subsubsection{Budgeting Processes in Public Sector before the emergence of ICTs}

According to Malgwi and Unegbu (2012), the word budget originated from a French word bougette meaning little bag. It is a tool use by the government for planning and controlling government economic resources. Budgeting process in public sector has been characterized with a lot of delay and protocols. It is also a complex and time consuming one. According to chart generated by Adams (2009) as shown in Figure 1 below, it could be observed that, budgeting in Public Sector takes a longer period of time.

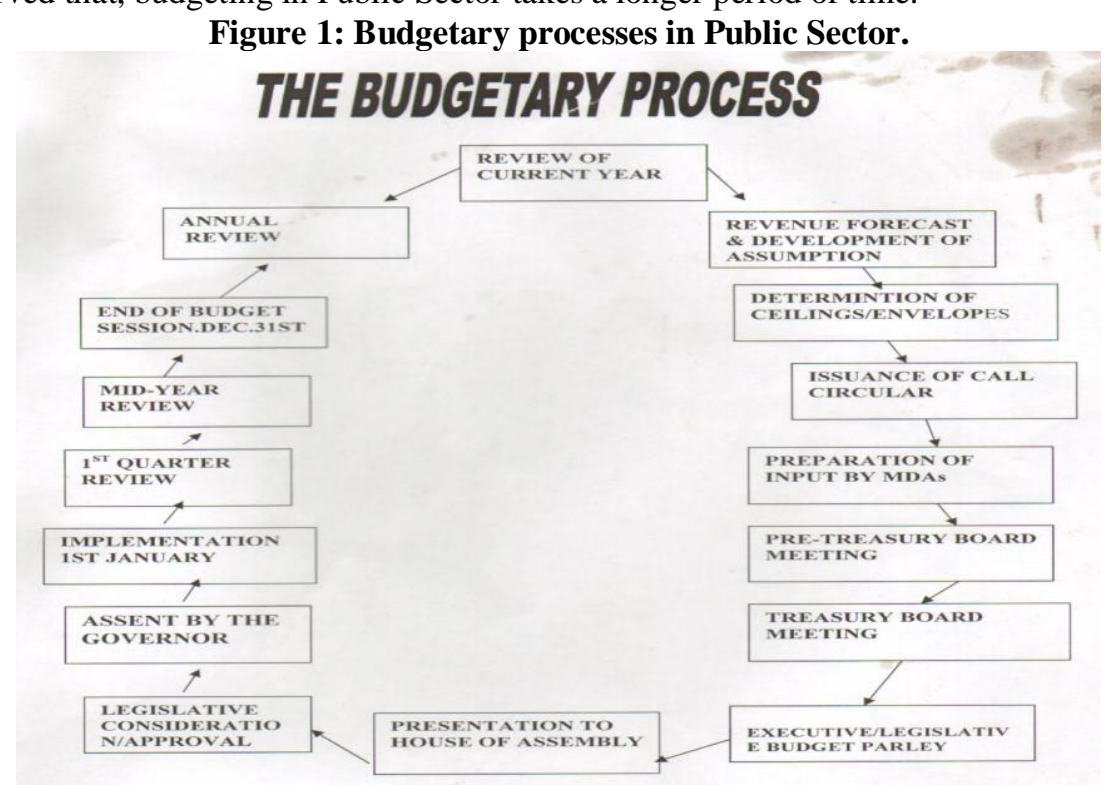

Source: Adams, R. A. (2009). 
Although figure 1 above shows budget process from beginning to the end (i.e. pre-implementation, implementation and post-implementation stages), this study is considering only pre-implementation budget processing period and does not include the submission of the consolidated draft budget (Appropriation bill) for legislative approval.

\subsubsection{Traditional Budgeting Process in Public Sector}

According to Adams (2009) and ICAN (2009), (traditional) budgeting process in government ministries and extra-ministerial departments is a cycle of events which occur sequentially every year and which result in the approved budget. Before the recent development in the budgeting process in public sector engineered by ICT, normally the budgeting process usually commences around April every year. Ministry of Budget and Economic Planning (MEPB) usually receives policy pronouncements from the presidency (at the federal level). After this, the budget department of the Ministry of Budget \& Economic Planning later issued budget guidelines in form of call circular to respective Ministries, Extra-Ministerial Departments and Agencies (MDAs). Each MDA later form a committee of 'Advance Proposal' which acts as Pre-Treasury Board in order to appraise the various budget proposals received with respect to the fund available. The committee is headed by the Permanent Secretary or Minister of Finance (or Commissioner of Economic Planning and Budget) as the case may be. If the provisional approval is received, the proposed budget is transmitted to the Presidency or Treasury Board (headed by the State Governor). This stage is otherwise called Ministerial or Pre-Treasury Stage.

Later on, the Draft Estimates are presented to the Executive Council (Treasury Board) or Council of Ministers. After the Draft Estimates have been discussed, rectified and approved at the Treasury Board, it is forwarded to National or State Assemblies (as the case may be) in form of Appropriation Bill. This stage is referred to as Executive Council stage.

This is followed by the presentation of the Appropriation Bill by the President or Governor at the respective Assemblies otherwise called 'Budget Session'. The Bill is later considered by the already established Standing Committee of the Assembly. At the federal level, each arm of the National Assembly and State House of Assembly will approve the proposed budget after every necessary consideration has been made. However, if there is any divergent of opinions on some items of the proposed budget, this is attended to by a Finance Committee whose resolution on the matter is final. Finally, the budget is considered at the joint session (of the two houses of the National Assembly). This stage is called Legislative Stage.

The budget is later sent to the President or Governor for his assent which later turns the Appropriation Bill to an Act. The copies are then sent to various MDAs. This is referred to as Presidential or Governor Assent Stage.

\subsubsection{Budget Cycle in Ondo State before the Emergence of E-Budgeting}

The budget cycle refers to the different stages of processes which a budget passes through in order for it to accomplish the intended or desired objective. For Ondo State Government according to Olajorin (2012), the budget cycle spans an approximate 22 months period covering Conceptualization, Preparation, Implementation, Monitoring and Reporting processes.

Conceptualization (April - June): The following activities are carried out;

- Estimation of Revenue Projection

- Preparation of Policy Guidelines

- Determination of Revenue Envelopes

- Other Pre-Call Circular Activities

Preparation (July - December): The following functions are performed.

- Issuance of Call Circular

- Pre-Treasury Board Meeting

- Treasury Board Meeting

- Presentation to House of

- Assembly/Legislative Defense

- Legislative Approval

- Signing into Law

Implementation (Jan - Dec): Here, the approved budget is being implemented.

Monitoring: (Jan - Dec): It involves the following functions;

- Monthly Rendition of Reports

- Revenue tracking

- Budget Officers Meeting (Monthly) 
Reporting (Jan- March of succeeding year): The report may be made as follows;

- Quarterly Report

- Mid Year Appraisal

- Full Year Appraisal

\subsubsection{Government Bureaucracy and ICT Budgeting Process}

Bureaucracy in government is a challenging impediment to timely budget processing in public sector. According to Banjoko (1996:98), bureaucracy has greatly hampered performance and efficiency in government ministries and parastatals. Historically, bureaucracy is referred to as government administration managed by departments staffed with nonelected officials. It is a system of government or business that has many complicated rules and ways of doing things (Ronald \& Gary, 1994). It is criticized by its complexity, inefficiency, and inflexibility. Traditionally, before a budget is approved, it has to move forward and backward for several times within the time frame from the smallest unit up to the legislative before it is approved.

This implies that budgeting in public sector is faced with delay associated with bureaucratic feature of government. Thus, Government employs these vital instruments (ICTs) in the management of their economic landscape, now that ICT is been used and applied in virtually every facet of human endeavors (Ashrafi and Murtaza, 2008; Villalva, n.d).

\subsubsection{Essence of Budget in Public Sector}

Budgeting in the public sector shares many similarities with the private sector but contains a greater focus on the relationship with policy development, performance monitoring and statutory objectives. The key objectives of public sector budgeting include; Assisting in planning expenditure to meet policy requirements; Policy implementation and control; Measuring and monitoring performance; To determine the total expenditure of the organization and ensure that it is consistent with total revenues (e.g. fixing the rate of local taxation); Provide the basis for authorizing expenditure and collection of fees and charges; Provide the basis for budgetary control; Satisfaction of statutory requirements.

\subsubsection{Current Developments in the Public Sector and their Impact on Budget Processing}

In the recent years the public sector has faced many challenges due to the rapid pace of changes both in the way services are delivered and in organizational structures/relationships. These changes have meant that the finance and budgetary functions of government should adjust to accommodate different ways of working and delivering services and to play a key role in developing and maintaining effectiveness. As new policy developments are introduced, the need for effective governance and budgetary control arrangements to ensure probity and sound financial management remain undiminished.

Budget processing consists of activities that encompass the development, implementation and evaluation of a plan for the provision of services and capital asset. Several essential features that characterize a good budget processing include; Incorporating a long-term perspective; Establishing linkage to broad goals; Focusing budget decisions on results and outcomes; Involving and promoting effective communication with stakeholders; Providing incentives to management and employees and Focusing budget decisions on results.

These key characteristics of good budgeting make it clear that the budget processing is not simply an exercise in balancing revenues and expenditures one year at a time, but it is strategic in nature, encompassing a multi-year financial and operating plan that allocates resources on a basis of identified goals.

A good budget process moves beyond the traditional concept of line item expenditure control, providing incentives and flexibility to managers that can lead to improved program efficiency and effectiveness.

\subsubsection{Budgeting Processing in Public Sector with the use of ICT (E-budgeting)}

Although many people may have made moves for the implementation of e-budgeting in Ondo State in the time past but the record of such were not available in the MDAs. The current effort was an initiative of the current leadership of the Ministry. The effort was made in the year 2010 when new officers were recruited into the Civil Service by the state government. Some Programme Analysts among them were asked to think on how to develop a package that will improve the budgetary processes of the state and what they came up with was what we have today (i.e. online budgeting platform). The use of e-budgeting in the MDAs can be summarized as follows:

- Introduced and Web-portal was created in 2010

- E-budget Web Portal deployed

- MDAs submit budget proposals online real time

- All proposals electronically collated, analyzed (including summations) and presented in a printable format

- The budget of the State is presented online for everybody to see. 
- The preparation stage only opens to the active participants, that is, only authorized Ministries, Departments and Agencies can input their budget proposals, the public can only view the budget for the current year after it has been passed into law.

The use of ICT in budget preparation by government Ministries, Departments and Agencies (MDAs) in Nigeria is on the increase. This is because of the positive impact ICT plays in this regards. While some states have deployed ORACLE (such as Lagos State) as platform for preparing their year budget, others have gone online (Olajorin, 2012). The online platform enables government MDAs to submit their budget proposal online. This has tremendously impacted positively on the entire budgetary processes and it has given opportunity to the members of the public to make meaningful contributions to the development of their state as states (such as Ondo State) are beginning to have Public Participation Module in their portal to give room for participation of "ordinary" citizen in the budgeting process.

The online budgeting system has made the job of budgeting easier than when excel template was being used. Devices used include; Laptops, Model, router etc. In the days when conventional mean was used, several challenges were encountered which made budget preparation very cumbersome and time consuming. The deployment of e-budgeting system has greatly reduced most, if not all, of these challenges. ICT now enables (budget processing) information to travel very fast (Benefit of Using ICT in Learning for Development, n.d)

\subsubsection{Impacts of ICT on budget processing in Ondo State, Nigeria}

a. It improves the communication and response time: The Ministry of Finance/Economic Planning no longer use the convectional way of conveying information to Ministries, Departments and Agencies which usually takes longer time to move from one place to another. The ministry, through the introduction of ICT can communicate through the internet and responses will be got almost immediately. Also, to send "Call Circular" to MDAs, the ministry need not sent an officer to go around, it only sends it via the internet and all Ministries, Departments and Agencies will get the information at the same time in their mail box. Generally, there is reduction in time spent during budget preparation. The Budget Officers do not need to type in any existing "head"; it is just click and add operation.

b. It guides the MDAs on prudent allocation of funds through the envelope/Ceiling: It makes Ministries, Departments and Agencies know their total allocation for the year and does not give room for overbudgeting. This is a very great achievement on the part of ICT in budgeting processes. Ministries, Departments and Agencies have the habit of submitting much more than the Ceiling given to them and by so doing, they give the Budget Office a very big problem on how to reduce the budget to one that can be accommodated by the limited available fund. The staff of the Budget Office may need to go sleepless for days to meet up with the date for the Pre-Treasury, Treasury Meetings and Presentation by the Executive (Governor) to the Legislature (House of Assembly) for passage. Since Ministries, Departments and Agencies now get their ceilings online; they cannot input more than what is given in their envelope/ceiling. The over-budgeting issue is being taken care of by tying their input strictly to the ceiling given them and the system will not allow any increase, no matter how small. This has brought about great reduction in total time spent on budget preparation in such state(s).

c. There is Elimination of errors as regards total sum of figure during budget preparation: Due to human error while trying to compute the total of some figures, incorrect values are often generated and this may not allow the ministry to get the expected value. This will make the officers to spent so much time trying to check figures and values and do the computations all over again but with the use of ICT, there cannot be summation error and if there is any conflict in the expected figure and the one generated it must have been due to a wrong entry of figure by the Officer and not due to calculation error on the part of the program. The advent of ICT makes figure accuracy a simple task to carry out. The automated system only requires that data be entered and summation is done automatically.

d. Security of data: The entries by Ministries, Departments and Agencies are much secured as no other MDA can see or view what a particular MDA has entered. All unauthorized persons are also kept aloof.

e. Data Integrity: the integrity of the entries by the Ministries, Departments and Agencies is highly guaranteed because no other user can manipulate, delete or edit what has been submitted by any MDA. There is also flexibility in the use of ICT for budgeting in that in case there is need for any MDA to correct any information already supplied, he/she can just login to the portal anywhere, anytime, any day and edit such information provided the date for submission has not expired. 
f. $\quad$ Easy Access and User friendly: There is easy access to the platform in as much as there is internet connection and to input your data is very easy as the platform is user friendly; that is, the users can easily key in their data without anybody guiding them. Also, the users do not necessarily need to be in the office before he can do his work.

g. Automatic Update: automatic update of records is done once in a year by the program during which necessary adjustments are carried out by the e-budgeting system. This is to prepare the system for the following year's budget.

h. The MDAs can print their budget proposals/approved budget anywhere and at any time.

At the Administrative level: The Administrator benefits the following from the deployment of e-budget in the State

a. Envelope: This has been done in such a way that no MDA can exceed the Envelope allocated to it. This solved the problem of over-budgeting encountered in the past.

b. Control: Administrator has the power to restrict any MDA that fails to meet up with the time given to them for budget preparation by disallowing them from gaining access to the portal.

c. All MDAs have the same opening/ closing date for their budget preparation.

d. Administrator can view what each MDA is submitting immediately as they are keying in their data.

e. The overall processing time is reduced.

f. Collation: Collation is done automatically as MDAs are submitting their data. No further calculation is done as the system has been programmed to do auto-summation.

g. Control: The Administrator has overall control on the system.

h. Printing of the Overall Budget: The overall budget can be printed immediately after the budgeting processes are completed.

i. The Administrator generates the overall result which is printed as the State budget for the year in view.

\subsection{Budgeting Theory:}

According to Irene (2007), "theory in budgeting, like much of public administration, has been of two kinds. That is, descriptive and normative theories. Descriptive theory is based on close observation or participation in public sector activities. These theorists describe trends, sequences of events, and infer causes, paying attention to local variations as well as uniformities across cases. Normative theory (advice) may be based on a much narrower range of observations than descriptive theory and its proposed solutions may be based on values rather than observations. If the explanatory power of the descriptive theory is too weak, or if the advice of normative theory is not adopted by public officials or is adopted and abandoned because it does not work, the gap between theory and practice may become unacceptably wide."

\subsection{Empirical Review:}

Several authors have written several papers on the impacts of ICT at one point or the other. Stea and Harindranath (n.d) explored the relationship between public sector ICT management strategies and electronic government and submitted that the bureaucratic structure and culture of the public agency play a key role in the type of ICT strategy adopted and that it has repercussions for the outcome of its e-Gov programme. Kehbuma (2005) also studied and reviewed the analysis of the scholars in order to judge the overall significance of the role of internet in promoting social change. The result of the empirical study of Rajiv, Hsihui \& Yi-Ching (2002) indicated that, there were significant productivity gains following Information Technology (IT) implementation, documenting the value impact of IT in public accounting firm. Adewoye and Akanbi (2012) empirically obtained that sachet water companies should be ICTs compliance as a result of the substantial role it play on the business. Base on these above findings concerning the use of ICT among numerous others, it could be inferred that indeed ICT has impacted on several facets of life particularly in public sector. However, it could be submitted that little or no study has been done on the impact of ICT on budgeting processes in public sector.

\section{Methodology}

The study specifically relies on both primary data obtained from 'the State' where ICT is used for budgeting processes in Nigeria. The study was carried out in Ondo State, Nigeria where ICTs have been deployed to budget processing in MDAs. Samples were obtained from all the MDAs within the state. Samples were made up of level 8 and above staff of budgeting unit from each MDAs. It is believed that these set of respondents possess better knowledge and understanding of questions raised on the questionnaire so as to provide adequate response towards attaining the objective of the study. A well structured closed-ended questionnaire was used to obtained response from the selected respondents using purposive sampling technique. 95 copies of the questionnaire were distributed; 92 copies were returned and used for the analysis. 
The study employed both descriptive and inferential statistics to analyze data collected. Descriptive statistics employed percentage, frequency and mean scores to analyze responses of respondents on all questions raised on the questionnaire with attempt to answer all research questions while inferential statistics was carried with the use of chi-square to test four null hypotheses raised at 0.05 level of significance.

\subsection{Descriptive Analysis}

\section{Discussion of Findings}

Descriptive statistics was carried out by obtaining summary measures (frequency, Percentage and means) of ICT devices used, MDAs belong, whether they use ICT to process budget and prefer ICT to than manual way of processing budget. Mean between 1.0 and 2.49 were regarded as low responses while any mean between 2.5 and 3.0 is regarded as high. Considering the response of the respondents to ICT devices used, all the respondents except one indicated that they used one device or the other to process their MDAs' budget with a mean of 2.97; 39 respondents (representing 42\%) indicated that they use laptop only while 4 respondents (representing 4\%) indicated that they use routers. 30 respondents (representing 33\%) showed that they use both laptop and modem to process their MDAs budget while the remaining 18 respondents indicated that they used all the three devices.

As to MDAs the respondents belong, only one respondent did not indicate MDAs belong. 47 respondents (representing 51\%) indicated that they were from government Agencies, 21 respondents showed that they were from Extra-Ministerial Departments while the remaining 23 respondents indicated that they were from Ministries. Concerning question on whether they use ICT to process their budget, 83 respondents (with a mean score of 2.87) indicated positive response (i.e. Agreed). The mean response of the respondents to a question demanding whether they prefer the use of ICT to process their MDAs budget to Manual/Traditional way was 2.68 .

Table 1: Descriptive Statistics Showing Means and Standard deviation Result

\begin{tabular}{|l|l|l|l|l|l|}
\hline & $\mathrm{N}$ & Mean & Std. Deviation & Minimum & Maximum \\
\hline You think computer process budget faster & 92 & 2.9239 & 37014 & 1.00 & 3.00 \\
The use of ICT has reduced budgeting time & 92 & 2.8804 & .46510 & 1.00 & 3.00 \\
With ICT, you can process your budget within 48hour & 92 & 2.7935 & .60289 & 1.00 & 3.00 \\
\hline The use of ICT has reduced budget processing cost & 92 & 2.7826 & .50982 & 1.00 & 3.00 \\
You think ICT can further reduced budget processing cost & 92 & 2.6848 & .62774 & 1.00 & 3.00 \\
\hline Use of ICT has reduced bureaucracy in budget processing & 92 & 2.6522 & .70219 & 1.00 & 3.00 \\
Use of ICT has eliminated budget bureaucracy & 92 & 2.5870 & .69775 & 1.00 & 3.00 \\
\hline ICT has brought better control to budget processing & 92 & 2.6848 & .72520 & 1.00 & 3.00 \\
\hline
\end{tabular}

Source: SPSS Result

\subsection{Inferential Statistics}

This section presents the result of test of null hypotheses proposed to statistically establish how ICT has impacted on budget processing in MDAs.

$\mathbf{H}_{\mathbf{O}}$ 1: The use of ICT to capture budget information has no significant effect on budget processing speed in MDAs.

Table 2: Chi-Square Test Statistics

\begin{tabular}{|l|l|l|l|l|}
\hline & $\begin{array}{l}\text { You think computer process } \\
\text { budget faster }\end{array}$ & $\begin{array}{l}\text { The use of ICT has reduced budget } \\
\text { processing time }\end{array}$ & $\begin{array}{l}\text { With ICT, you can process your budget } \\
\text { within 48hour }\end{array}$ \\
\hline Chi-Square & $160.848^{\mathrm{a}}$ & $150.022^{\mathrm{a}}$ & $129.935^{\mathrm{a}}$ \\
Df & 2 & 2 & 2 \\
Asymp. Sig. & .000 & .000 & .000 \\
\hline
\end{tabular}

a. 0 cells $(0.0 \%)$ have expected frequencies less than 5 . The minimum expected cell frequency is 30.7 .

Source: SPSS Result

Interpretation: Table 2 above shows the calculated $\chi^{2}$ of three questions raised to find out the impact of the use of ICT in capturing budget information on budget processing speed. The three questions show that a positive relationship exist between the use of ICT in capturing budget information and budget processing speed with calculated $\chi^{2}$ of $160.85,150.02$ and 129.94 respectively which are greater than critical value. The p-value at 0.05 level of significance was 5.99. Since the p-value is less than calculated $\chi^{2}$, then the null hypothesis is rejected which provides basis for accepting alternate hypothesis. Thus, the use of ICT to capture budget information has significant positive effect on budget processing speed in MDAs. This is in consonance with the descriptive findings on the three questions with means of 2.92, 2.88 and 2.79 respectively which are above the targeted minimum mean of 2.5. This shows further that computer and other related budget processing ICT devices, 
process budget faster, reduce budgeting time and thereby allow MDAs' budget to be processed and submitted within 48 hours.

$\mathbf{H}_{\mathbf{O}}$ 2: There is no significant reduction in the cost of budgeting in MDAs after the introduction of ICT.

Table 3: Chi-Square Test Statistics

\begin{tabular}{|l|l|l|}
\hline & $\begin{array}{l}\text { The use of ICT has reduced budget processing } \\
\text { cost }\end{array}$ & $\begin{array}{l}\text { You think ICT can further reduce budget processing } \\
\text { cost }\end{array}$ \\
\hline Chi-Square & $101.565^{\mathrm{a}}$ & $79.978^{\mathrm{a}}$ \\
Df & 2 & 2 \\
Asymp. Sig. & 000 & .000 \\
\hline
\end{tabular}

Source: SPSS Result

Interpretation: From Table 3 above, the calculated $\chi^{2}$ on the proposition that the use of ICT has reduce budget processing cost shows 101.57 while that of the respondents perception that the use of ICT can better reduce budget processing cost shows 79.98. At 5\% level of significance, critical value shows 5.99. Since p-value is less than calculated $\chi^{2}$, this provides ground for rejecting null hypothesis. Thus, there is a significant reduction in the cost of budget processing in MDAs after the introduction of ICT and that it will reduce the cost further.

$\mathbf{H}_{\mathbf{O}}$ 3: There is no positive impact of the use of ICT to process budget in MDAs on associated government bureaucracy

Table 4: Chi-Square Test Statistics

\begin{tabular}{|l|l|}
\hline & Use of ICT has reduced bureaucracy in budget processing \\
\hline Chi-Square & $83.826^{\mathrm{a}}$ \\
Df & 2 \\
Asymp. Sig. & 000 \\
\hline
\end{tabular}

Source: SPSS Result

Interpretation: Table 4 above presents calculated $\chi^{2}$ on the proposition that the use of ICT has reduced bureaucracy associated with budgeting process in MDAs with a positive value of 83.83. The p-value shows 5.99 at 0.05 level of significance indicating that, calculated $\chi^{2}$ is greater than critical value. Thus, the null hypothesis is rejected while the alternate will hold. That is, bureaucracy that is prevalent in government sector specifically in MDAs which could be traced to delayed or poor budget processing has been reduced with the use of ICT.

$\mathbf{H}_{\mathbf{O}}$ 4: The use of ICT to process MDAs' budget does not provide better control on its budgeting process.

Table 5: Chi-square Test Statistics

\begin{tabular}{|l|l|}
\hline & ICT has brought better control to budget processing \\
\hline Chi-Square & $107.761^{\text {a }}$ \\
Df & 2 \\
Asymp. Sig. & .000 \\
\hline a. 0 cells $(0.0 \%)$ have expected frequencies less than 5. The minimum expected cell frequency is 30.7. \\
\hline
\end{tabular}

Source: SPSS Result

Interpretation: Chi-square result of the proposition that ICT has brought better control to budget processing in MDAs is presented in table 5 above. The calculated $\chi^{2}$ shows 101.76 while its p-value shows 5.99 , which is significant at 0.05 . Since the table value is less than calculated $\chi^{2}$ then, the null hypothesis is rejected. Thus, the adoption of ICT in MDAs provides better control on its budgeting process.

The result of the first hypothesis $\left(\mathrm{H}_{\mathrm{O}} 1\right)$ shows that, indeed ICT has helped speed up budget processing time and thereby reducing long period of time used under manual or traditional way of processing budget in MDAs. This implies that, to ensure timely collation and readiness of MDAs' budget for onward processing by the parliament, ICTs play a crucial role.

As indicated by the statistics result of second hypothesis $\left(\mathrm{H}_{\mathrm{O}} 2\right)$, it is clear that there is a significant reduction in the amount government expends on the budget processing in MDAs if ICT is used to carry out the job and that, it will reduce further in the long run. The result of hypothesis three $\left(\mathrm{H}_{\mathrm{O}} 3\right)$ indicates that there is a positive and significant impact of the use of ICT to process budget of government's MDAs on bureaucratic feature of the government. This might be as a result of the fact that there is no need of sending the draft budget 'up and down' from various units or MDAs to Ministry of Economic Planning and Budgeting or Finance (as the 
case may be) before approval. All you need to do when the site is open for each MDAs to submit its budget is to $\log$ on, fill the necessary options by inputting certain amount that is not above the already key-in vote, then submit. Finding of hypothesis four shows that the use of ICT to process MDAs' budget provides a better control on its budgeting process. This indicates that, once you key-in your budget data and submits, it is automatically accepted for collation. It also in consonance with the finding that the use of ICT to process the budget will reduce associated cost.

\section{Conclusion and Recommendations}

The study concludes that the use of ICT to process MDAs budget is indeed a right step government at all levels should take as it hasten and speed up collation of budget, reduce government bureaucratic ways of doing things, reduce the cost associated with traditional or manual way of processing budget as well as providing better control over budget processing. Thus, the study recommends that the use of ICT to process budget at all levels of governments should be encouraged while capable and competent hands should be brought in, to handle the ICT-based budget processing devices.

\section{References}

[1]. Adams, R. A. (2009). Public Sector Accounting and Finance Made Simple. Revised Edition 2; Lagos: Corporate Publishers Venture.

[2]. Adewoye, J. O. \& Akanbi, T. A. (2012). Role of Information and Communication Technology Investment on the Profitability of Small Medium Scale Industries - A Case of Sachet Water Companies in Oyo State, Nigeria. Journal of Emerging Trends in Economics and Management Sciences 3(1): pp 64-71

[3]. Agbolade, O. K. (2011). Information and Communication Technology and Banks Profitability in Nigeria. Australian Journal of Business and Management Research 1(4). pp 102-107.

[4]. Ashrafi, R. and Murtaza, M. (2008). Use and Impact of ICT on SMEs in Oman. Electronic Journal Information System Evaluation, 11(3). pp 125-138.

[5]. Banjoko, S. A. (1996). Production and Operation Management. Pumark Nig Ltd, Ibadan.

[6]. Benefit of Using ICT in Learning for Development (n.d). Effective blended Learning for Development

[7]. Gatautis, (2008)

[8]. Irene, S. R. (2007). Budget Theory and Budget Practice: How Good the Fit? Retrieved from http://www.jstor.org/journals/aspa.html on $20 / 8 / 2012$

[9]. ICAN Study Pack (2009). Public Sector Accounting and Finance. Lagos: V I Publisher

[10]. Kehbuma, L. (2005). The Role of ICT in the Economic Development of Africa: The Case of South Africa. International Journal of Education and Development Using Information and Communication Technology, 2(4) pp. 144-156.

[11]. Malgwi, A. A. and Unegbu, A. O. (2012). Budget in Nigerian Public Sector: Need for Balanced Scoredcard Perspective. International Journal of Finance and Accounting 1(2) pp 1-6.

[12]. Planning and Budgeting Process in Tanzania. Ministry of Finance and Economic Affairs Retrieved from http://www.tenmet.org/1 goaltanzania/BUDGET

[13]. Rajiv, D. B., Hsihui, C. and Yi-ching, K. (2002). Impact of Information Technology on Public Accounting Firm Productivity. Journal of Information System, 16(2) pp 209-222.

[14]. Ronald, N. J. \& Gary, D. L. (1994). The Federal Civil Service System and the Problem of Bureaucracy. University of Chicago Press pp 1-11

[15]. Harindranath, G. and Sien, M. K. (2007). Revisiting the Role of ICT in Development. Proceeding of the $9^{\text {th }}$ International Conference on Social Implications of Computer in Developing Countries, Sao Paulo, Brazil.

[16]. Stea, B. and Harindranath, G. (n.d). Public Sector ICT Management Strategy and its Impact on E-Government: A Case Study. Retrieved from http://is2.1se.ac.uk/asp/aspecis/20060095.pdf

[17]. Understanding the Budget Process in Tanzania: A Civil Society guide retrieved from http://www.policyforum-tz.org/files/English

[18]. Villalva, A. (2010). The Role of ICT. Retrieved from http://EzineArticle.com

[19]. Zimmermann, P. and Finger, M. (2005). Information and Communication Technology (ICT) and Local Power Relationships: An Impact Assessment. The Electronic Journal of e-Government 3(4) pp 231-240 